\title{
Essays
}

\section{A Wilderness of Mirrors: Perspectives on 'the Spying Game' in Australian Literature}

\author{
Bruce Bennett, University of NSW at ADFA, Canberra
}

Although spying is pervasive throughout Australia's history, we have had fewer examples than Britain or the USA, our senior partners in espionage, of spies or spooks who have 'come out', before or even after their retirement, and declared their hand. (A notable exception is Michael Thwaites, who supervised the defection of Vladimir Petrov for ASIO in the early 1950s. Another is Andrew Wilkie who resigned from Australia's senior intelligence agency, the Office of National Assessments, in protest against the impending Iraq war in 2003.) Yet a neglected and growing literature can be discerned that testifies to Australians' continuing involvement in spying, since the earliest explorations of our coasts (Bennett). This literature offers considerable insights into human behaviour and thought. At a time when intelligence agencies are recruiting at an increasing rate throughout the world, attention is turning to a buried part of Australia's national and international life. Along with this, we see more frequent attention to espionage not only in spy thrillers but also in essays, memoirs and novels in which espionage is an important element. ${ }^{1}$

The principal focus in this paper is on four novels by Australians published from the 1990s which engage significantly with 'the spying game': Ric Throssell's In a Wilderness of Mirrors (1992), Frank Moorhouse's Grand Days (1993), Christopher Koch's Highways to a War (1996) and Janette Turner Hospital's Due Preparations for the Plague (2003). Each of these novels throws light - a shimmering, refractive light - on the profession of espionage and its impact on individuals. A picture emerges of mobile, trans-national individuals engaged in clandestine activity which tests their intelligence, commitment and conscience and brings into question the causes they purport to serve.

The cover picture of Throssell's novel In a Wilderness of Mirrors shows a recognisable likeness of the author in his middle years wearing mirror sunglasses that reflect the light and prevent any glimpse of the eyes. The temptation is thus placed before the reader to identify the author with the novel's protagonist, the spy Selwyn Joynton, but Throssell warns against any such easy identification in the book's Epilogue: 
And Selwyn Joynton - there was a man like that. He is dead now, and I suspect never was my Selwyn, not wholly. Not at all perhaps; but he might have been... Not me. I never was the man he saw in the mirror of his mind. (196)

The syntax, imagery and rhythms here are deliberately elusive and bring to mind the genealogy of the phrase that serves as the novel's title. 'In a wilderness of mirrors' harks back to 'Gerontion', T.S. Eliot's poem of world weariness, confusion and spiritual desiccation. The poem's speaker partially identifies himself in the lines:

Here I am, an old man in a dry month, Being read to by a boy, waiting for rain...

He has lost the ability to make real contact with others, and is left to 'multiply variety/ In a wilderness of mirrors' (37-9).

Throssell's novel does not acknowledge T.S. Eliot's poem as his source: in an epigraph he attributes the phrase to James Jesus Angleton, head of counterespionage in the CIA who used the phrase to refer to the bewildering array of disinformation and lies fomented during the Cold War. Angleton read complex poetry, including Eliot's, cultivated orchids and is one of the 'honourable men' in former CIA director William Colby's memoir, before Colby sacked Angleton for believing in illogical conspiracy theories about CIA colleagues when there was no evidential basis for them $(364-5,377-8,396)$. (A number of commentators have speculated on Angleton's tendency to see conspiracies all around him following his deception by Kim Philby, the British-born spy for the KGB.) At any rate, Angleton felt himself ensnared in what he perceived as a wilderness of mirrors, and is also credited with having popularised this phrase as it applied to the intelligence profession in the Cold War.

Throssell adapts the motif neatly to the world of espionage which his character Selwyn Joynton inhabits. Imagery of mirrors recurs throughout the novel, commencing with Throssell's dedicatory poem at the beginning to his granddaughter in which he purports to address the child while he shaves:

Child of my child,

In the three faced mirror you gaze

Full of the wonder of living... 
Childish wonder and innocence contrast with the man's sense of world-weary experience. In the body of the novel, the author returns recurrently to images of Selwyn Joynton, the deliberately faceless man who makes a living by seeming unremarkable, observing himself in a series of mirrors.

From his orchard in the Dandenongs outside Melbourne, Selwyn lives a cover life as a London-based international journalist with a small import business, while supporting his Italian wife and two children who live there. On one of his return visits to Australia, Selwyn looks at himself in the wing-backed shaving mirror with its multiple reflections:

His eyes above the top of the hand towel caught the reflection of his image in the mirror: a familiar stranger, every line and plane of his face known, absorbed into the matrix of recognition; but alien nevertheless, different. Selwyn did not see the face in the mirror as himself. It was a mirror image of Selwyn Joynton, no more, like the face that had looked back at him at the Moskva - when was it? That stranger always there, watching. (Throssell 334)

Throssell's characterisation of Selwyn Joynton does not allow Joynton deep reflections. We are not offered an 'inner life', perhaps because he does not have one. The English-born Joynton seems to have no fixed centre, no philosophy he lives by, no place of belonging - except perhaps in the love of his daughter and her love for him. Both his wife and son seem to dislike and resent Selwyn as an interloper during his sporadic returns from secret adventures overseas. In an outburst before she is hospitalised as a schizophrenic, his wife Marietta accuses her husband of being a liar and a traitor. Both charges seem true. When Marietta dies, possibly by her own hand, Selwyn feels a vague guilt but manages to slough it off. He also feels a residual bitterness that he has failed to reform the world as an earlier youthful self had apparently set out to do. But he has always been compromised. Stated thus, Throssell's spy might seem to have the makings of a Le Carré character, but Selwyn Joynton is no Magnus Pym, or indeed George Smiley. Selwyn's flashbacks are often fleeting and insubstantial as though he himself has relegated them to a tiny corner of his mind. Elizabeth Perkins captures the figure as Throssell presents him. To her, he seems 'a minor devil dispatched from the hell of international power play' (Perkins 148). This image is attuned to Throssell's left-liberal inclinations but does not fully account for the author's apparent sympathy with aspects of Selwyn's character.

The roots of Selwyn Joynton's career as a spy are shown in his student days at university in Melbourne, where he was an anti-conscription activist during the 
Vietnam war. But the 'Pom', the fat boy from England, never seems quite 'in step' with his fellow protesters: indeed, he seems to be an informer for ASIO. Later, he is 'run' from London where he is assigned by MI6 to Uganda with cover as a journalist. He refers to himself ironically as "our man in Kampala", echoing Graham Greene's Our Man in Havana (Throssell 71). This is the first of three undercover operations in the novel which are associated with attempted coups against socialist governments, the other two being in Grenada and the Seychelles. Throssell had visited each of these places and researched the crises: he inserts his shadowy protagonist into these neo-colonialist adventures while revealing the highly dubious and sometimes absurd nature of the British and American, and in the case of the Seychelles, Rhodesian interventions.

The actual events on which Throssell draws for his accounts were carefully researched. This is evident in the episode of the American airborne invasion of the Caribbean island of Grenada in 1983. In the novel, Selwyn Joynton is the secret emissary to the governor of the island, persuading him on behalf of the British and American governments to invite their intervention following the murder of Prime Minister Maurice Bishop. But the novel presents the American adventure from varying perspectives, with mixed motives and conflicting views on the action. A recent memoir by the actual CIA chief in charge of 'the Grenada episode' has presented the events from an entirely ethnocentric American point of view. The military were keen to intervene, Duane ("Dewey") Clarridge writes: "No one wanted to be left out of the first military action since Vietnam, but this zeal had virtually nothing to do with Grenada, and everything to do with justifying military budgets on Capitol Hill" (255). Visiting Grenada after the intervention, Clarridge was given a military bumper sticker which he placed on his own Jeep. It read: 'WE KICKED ASS IN GRENADA!' (268). The "fog of war" thinking which Robert McNamara retrospectively described in America's involvement in the Vietnam war, had apparently not lifted some eight years later, when a small and relatively harmless target could somehow restore battered military egos in the world's most powerful nation.

Why then, despite Throssell's apparent disapproval of the Grenada intervention and the others in which his protagonist appears does the author give his spy almost sympathetic attention? Is this literary tact? Or is Throssell projecting an understanding of someone deeply involved in an espionage mindset? Throssell, the son of Katharine Susannah Prichard, had in fact lived most of his adult life under suspicion of having spied for the Soviet Union. He had fought doggedly to clear his name from the slur cast upon it by the evidence of the Soviet defector Vladimir Petrov in 1954. He had made some headway. But when in 1996 the Venona decrypts of KGB cables between Canberra and Moscow were released, it became 
clear that Petrov was right: his colleagues at Moscow Centre had stated that Throssell (codenamed "Ferro") had passed valuable information to the Russians (Ball and Horner 270). This still did not prove that Throssell had spied but it was sufficient for some Australian newspapers to reiterate the view that Throssell was a Soviet spy (eg Courier-Mail, Age). ${ }^{2}$

When I asked David McKnight, author of Australia's Spies and their Secrets, if he considered Ric Throssell a spy he said he thought that this was still an open question. He quoted Alan Renouf, an experienced diplomat: 'The door never closes'. ${ }^{3}$ The door closed however for Throssell in 1999 when, in good health, he took his own life, in a double suicide with his wife who had also been under suspicion by the Royal Commission on Espionage. Did Throssell regret his life? From the late 1980s and early 90s when communism died and the Soviet Union collapsed, how did he see himself? Had he lived so long with the spectre of being a spy that when the mirror cleared he sometimes saw an image of himself there?

Frank Moorhouse's life has not been implicated in the world of espionage to the extent that Throssell's was. But Moorhouse remains one of Australia's most subtle observers of personal and political dilemmas. In Grand Days (1993), his novel about an Australian woman Edith Campbell Berry's induction into the complex international politics of the League of Nations, Moorhouse explores several facets of 'the spying game'. The chief site of espionage activity in Grand Days is the Molly Club in interwar Geneva. Here, in this trans-gendered, smoky, international setting, personal and sexual border-hopping seems not so far removed from the trading of secret information.

For Edith, an Australian idealist of her time, a crisis occurs when she discovers that her bisexual lover Ambrose is spying for the British. She reports this to her superior at the League who analyses the implications of Ambrose's spying and finds it less reprehensible than Edith had (Moorhouse 503).

I am indebted to Jane Stenning's excellent $\mathrm{PhD}$ thesis on moral pragmatism in Moorhouse and Lawson for pointing out the irony of Edith Berry's situation: that in "undoing a spy" - as Edith decides to do in Ambrose's case - she must "become a spy herself" (232-3). But Edith's boss at the League, Bartou, is a man of the world who observes that "To spy on a spy is no crime" (Moorhouse 504). As Stenning remarks, examining one's motives in such circumstances becomes "a vast tangle of perspectives and actions" and a coordinated response - a decision on how to act - is fraught with complications (233). 
These are Edith Campbell Berry's problems of conscience. When Ambrose's spying is exposed, his situation becomes a good deal worse: he is transferred to 'Siberia' - to a desk job in an unimportant department with little responsibility, where he suffers a nervous breakdown. These are the kinds of mental and emotional pressures, often complicated by sexual pressures, that biographies of the Cambridge spies - Philby, Burgess, McLean, Cairncross and Blunt - have related in varying degrees. Miranda Carter's superb biography of Anthony Blunt, the art historian and spy, and John Banville's novel based on Blunt, The Untouchable, demonstrate the scope for revealing this multi-mirrored wilderness in the respective genres of biography and novel.

\section{III}

Christopher Koch transports the dilemmas of the trans-national Australian with divided loyalties to Southeast Asia in his novel Highways to a War. One of the important puzzles investigated in this novel is whether, in addition to his work as a news cameraman, Mike Langford, the elusive protagonist of this novel, was ever a spy. Langford's own confessional remarks to his journalist friend Harvey Drummond are delayed until the concluding section of the novel, thus drawing the reader in as a co-investigator of the mystery of Langford's life. Mike tells Harvey that at the beginning of the war in Vietnam, as a news cameraman, he had passed on items of "operational intelligence" to Aubrey Hardwick, a member of the Australian secret service whom Mike had idolised. Hardwick has told Mike that his intelligence was important and had been accepted by the CIA and had even reached the White House (390). Mike Langford seems to have passed on this information out of youthful patriotic idealism.

Hawkish in his support for the Vietnam war in its early stages, Mike Langford is reported to have said that he later became a supporter of Lon Nol and the Free Khmer movement, believing that they still had a chance against the Khmer Rouge. Mike's love affair with Ly Keang has placed him romantically on the side of the "ordinary people" of Cambodia (393). When Ly Keang disappears, Mike sets out to find her, not knowing that she has been secretly recruited by his apparent friend and mentor Aubrey to be a stay-behind spy for the Australian secret service in Phnom Penh when the Khmer Rouge inevitably take control. In this sense, she is 'used' by the Australians. Worse perhaps, she is sacrificed to a lost cause. Mike's obsessive search for Ly Keang is unsuccessful. She has been killed by the Khmer Rouge. Mike himself, we learn at the novel's end, has been crucified by the Khmer Rouge who believe, ironically, that he is a CIA spy. The secrets and betrayals on which Highways to a War turns are closely intertwined with the world of espionage. 
The charming, ruthless and personally ambitious Aubrey Hardwick is Koch's iconic Anglo-Australian spook in this novel, for whom personal betrayals to obtain often flawed or misguided intelligence are part of the day's work. One of the founding figures of Australian intelligence under MI6's training and guidance, Hardwick seems to newsman Drummond "a little mad", like all spooks (386). Harvey observes that as one era gives way to another, reality becomes "a hall of mirrors: reality emulating some previous legend, and then itself becoming legend..." (391). Mike's dawning realisation, as he sees through the fog of disinformation and deceit, is that the Americans will not save Vietnam or Cambodia as he had once believed:

They'll shoot through soon and leave these people for dead: leave them to the Khmer Rouge. And the politicians and the spooks will go and start a new game. (391)

Mike's pessimism is prophetic: he sees no end to secret intrigues and treachery, and it appears there is none.

The "hall of mirrors image" of intelligence is not denied by Mills, who had been Mike Langford's case officer in Saigon in the 1960s but is rather confirmed by him. When Mills is questioned by Harvey Drummond over the ubiquitous bottle of whisky, Mills admits that personal relationships are early victims of "the spying game": "My marriage went years ago", he remarks. "[I]t didn't go with the game. Seldom does. The woman doesn't know who she's married to" (429). Recalling the fate of Ric Throssell's spy Selwyn Joynton, Mills admits: "You lose your personality in the end... For as an operative, the day comes when he's not quite sure who he is" (429). The early ideals, excitement and high hopes are dashed. Personal relationships wither. Confusion and sometimes despair set in. Is this what espionage is all about?

Koch does not offer a universal prescription of 'the spying game': the particular theatre of operations in Vietnam and Cambodia that he evokes has led to the despair of many Western participants and their friends. John Sullivan, a CIA agent who administered lie detector tests on Americans as well as potential Vietnamese and Cambodian recruits to American intelligence, has described himself as Diogenes in Vietnam. He explains: "Diogenes was a fourth century BC Greek philosopher and cynic who is often depicted carrying a lantern through the streets of Athens looking for an honest man - whom he never found" (159). Sullivan sees himself as playing that role in Vietnam. In Sullivan's view, the CIA was even more blind to the situation in Cambodia than it was in Vietnam. By the end of February 1975, Sullivan says only one question remained: when would Cambodia 
fall to the Khmer Rouge? (159). When Sullivan attempted to carry out polygraph tests on two potential "stay-behind" Cambodian spies for the CIA who would report back after the Khmer Rouge took over, they refused to cooperate. Their example of non-cooperation contrasts radically with that of Ly Keang in Koch's novel who meets her death while setting out to spy for Australia, having been persuaded to do so by an ambitious and self-interested senior spook. In the hall of mirrors, desires, motives and perceptions are very mixed.

The tragic historical irony that lies behind Koch's novel Highways to a War is that while America and its allies turned their attention after the calamity of Vietnam to Pinochet's military government in Chile and other trouble spots - cleverly incited in this to some extent by KGB masters of "hall of mirrors" propaganda - Pol Pot and his Khmer Rouge troops carried out a reign of terror in Cambodia which in three years killed 1.5 million of Cambodia's 7.5 million people (Andrew and Mitrokhin 88).

\section{IV}

We move now from Australian representations of espionage in interwar Geneva and Grenada in 1983, and Vietnam and Cambodia in the 1960s and 70s to America and the Middle East since the 1980s. Middle Eastern terrorism and aircraft hijackings provide the historical backdrop to Janette Turner Hospital's novel Due Preparations for the Plague. The novel draws specifically on the 1987 terrorist hijacking of Air France flight 46 and the calculated killing of its passengers, but was completed in the shadow of events in the USA now known by the shorthand expression ' $9 / 11$ '. Much of the imaginative and emotional appeal of Due Preparations for the Plague hangs on the impact of such terrorism on those who may survive, especially children. Twenty children were released before Air France 46 (code-named Black Death in the novel) was blown up by Middle Eastern terrorists. Two psychologically maimed survivors living in the United States, Lowell and Samantha, carry out the intelligence work, thirteen years after the event, that reveals CIA complicity in these tragic events.

Like other authors who appreciate the complexities and false trails of espionage and international politics, Turner Hospital employs imagery of fog and mirrors. Early in Due Preparations for the Plague, the young woman Samantha tries to imagine the spy code-named Salamander:

I spy

With my manifold eye. 
This is Salamander's morning canticle. He leans in close to the bathroom mirror and his words come back lush, fully orchestrated, thick with toothpaste and shower fog. He squints and sees galaxies: bright floating points, moons, multiple planetary rings. He has the eyes of a fly or god. The things that he knows; weighty matters of life and death, or swift death orbit his consciousness, but he must not speak of them. (49).

This is Samantha's construction of a mysterious figure she imagines from "undeleted half lines in documents" (49). Later, this figure becomes more fully known through videotapes and encrypted journals, which the real Salamander leaves for his son Lowell Hawthorne, and the records of a psychoanalyst. Salamander emerges posthumously as an agent who had become embroiled in an elaborate game of double-cross with a Middle Eastern agent codenamed Sirocco and was fatally outwitted in 'the spying game'. The tragedy of Black Death followed. His own death thereafter was assured.

Oddly, Salamander, the CIA agent who was implicated in the fatal hijacking, emerges retrospectively as a relatively sympathetic character. This is surprising given that his wife is killed and his son seriously scarred by events which he helped to set in train. What redeems him morally, to an extent, is his realisation that his son's generation should be spared the lunacy of which he has been a part. Moreover Salamander acts on this recognition, leaving his son a sports bag in a locker filled with the evidence that will expose the plots and counterplots in which he (and his country) have been involved in an attempt to make the world more 'secure'.

Turner Hospital's approach to the creation of her American secret agent becomes apparent in her interview with Peter Birnhaum (2003, n.p.):

Interviewer: Why choose such a life?

Janette Turner Hospital: People enter that world because they are highly trained and highly intelligent and go in out of idealism - we have a way of life and a system of government that needs to be preserved. And someone has to be in intelligence work to know who is planning to attack it. So you go in with idealism, but it is the nature of the task that it requires all sorts of decisions of short-term expediency, which can get very murky.

Turner Hospital's first thought before interviewing any former agents, was that they must be "cold-blooded". However, in talking with agents and trying to imagine Salamander more deeply, the novelist thinks of him as "increasingly 
tortured and anguished and unravelling, falling apart at the seams, going mad." Something of this state of mind is revealed in the psychoanalyst's reports to which Lowell Hawthorne and Samantha gain access.

The characterisation of Lowell Hawthorne's father is a remarkable feat and it seems churlish to criticise Turner Hospital for not giving equivalent depth to Sirocco, the spy from the 'other' side - as Brenda Niall claims Le Carré would have done (38). The moral and emotional complexities of life for children of spies have been captured in a recent biography, My Father the Spy, by John H. Richardson which shows the high psychological costs for individuals and their families of this profession. ${ }^{4}$ Each experience is no doubt different. But Turner Hospital, like Richardson, shows the deep desire of a son or daughter to know what has previously been secret and to revalue a parent whose life has been lived in the shadows.

A typical response of former intelligence operatives to novels and films about 'the spying game' is that they fail to capture the banality and drudgery of much of this work. Yet few would reject the notion that the major challenge in intelligence work is to see a way clearly through the masses of information and multiple perspectives produced by their own institutions and those of their enemies to the 'truth' of a situation.

In this "wilderness of mirrors" a certain clarity of mind, sense of purpose and above all, perhaps, imagination are required. A perhaps surprising source of this view is the 9/11 Commission Report which admits that "Imagination is not a gift usually associated with bureaucracies" and challenges Americans to find "a way of routinising, even bureaucratising, the exercise of imagination" in the intelligence services (344). While there may be benefits for the spy agencies in this approach, it would be an unfortunate by-product if the more free-ranging imaginations of novelists, filmmakers and others were restricted to the goals of national security in the US, Australia or elsewhere.

Novels such as those I have discussed by Throssell, Moorhouse, Koch and Turner Hospital offer unique insights from the outside into "the spying game" as an international phenomenon. They show the moral and intellectual complexities of espionage and the toll that this way of life can have on secret agents and those close to them. They show too the prevalence of spectres, screens, shadows and mirrors in a profession where 'spies' and 'lies' rhyme and truth is an open question. 
A shorter version of this paper was presented at the 2007 ASAL conference at the University of Western Australia.

\section{Bibliography}

Andrew, Christopher, with Vasili Mitrokhin. The World Was Going Our Way: The $K G B$ and the Battle for the Third World. New York: Perseus, 2005.

Ball, Desmond and David Horner. Breaking the Codes: Australia's KGB Network, 1944-1950. Sydney: Allen and Unwin, 1998.

Banville, John. The Untouchable. New York: Knopf, 1997.

Bennett, Bruce. "In the Shadows: The Spy in Australian Literary and Cultural History". Antipodes 20.1 (June 2006): 28-37.

Birnhaum, Robert. Interview with Janette Turner Hospital in identitytheory.com.

Posted November 11, 2003.

Carter, Miranda. Anthony Blunt: His Lives. London: Macmillan, 2001.

Charlton, Peter. "Former Diplomat's Life Marred with Tragedy“, Courier-Mail 22 April 1999:4.

Clarridge, Duane R., with Digby Diehl. A Spy for all Seasons: My Life in the CIA. New York: Scribner, 1997.

Colby, William. Honorable Men: My Life in the CIA. New York: Simon and Schuster, 1978.

Eliot, T.S. "Gerontion", The Complete Poems and Plays. London: Faber and Faber, 1969.

Hospital, Janette Turner. Due Preparations for the Plague. New York: WW Norton, 2003.

“Key Petrov Identity Dies“, Age 22 April 1999:4.

Koch, Christopher J. Highways to a War. Kew, Vic: Reed Books/Minerva, 1996.

McKnight, David. Australia's Spies and their Secrets. Sydney: Allen and Unwin, 1994. . Interview with Bruce Bennett, Sydney, 19 May 2003.

Moorhouse, Frank. Grand Days. New York: Pantheon, c. 1993.

Niall, Brenda. "Loading the Dice“, Australian Book Review (June/July 2003):38.

Perkins, Elizabeth. "Three Post-Colonial Novels: Fiction and a Political Conscience?" LinQ 19.1 (1992): 143-149.

Richardson, John H. My Father the Spy: An Investigative Memoir. New York: Harper Collins, 2005.

Stenning, Jane. Boundary Writers: Moral Pragmatism in Henry Lawson and Frank Moorhouse. PhD thesis. University of Sydney, 2006.

Sullivan, John F. Of Spies and Lies: A CIA Lie Detector Remembers Vietnam. Lawrence: University Press of Kansas, 2002. 
The 9/11 Commission Report: Final Report of the National Commission on Terrorist Attacks Upon the United States. New York: W.W. Norton, n.d.

Throssell, Ric. In a Wilderness of Mirrors. Sydney: Left Book Club, 1992.

Thwaites, Michael. Truth Will Out: ASIO and the Petrovs. Sydney and London: Collins, 1980.

Wilkie, Andrew. Axis of Deceit. Melbourne: Black Inc., 2004.

1 For example, Austlit: The Australian Literature Resource notes 16 literary items with espionage as a subject for the month of March 2006. A similar number of items is recorded most months.

2 The articles in the Courier-Mail and the Age both refer to Ball and Horner's book Breaking the Codes. Peter Charlton in the Courier-Mail notes that Ball and Horner 'established conclusively that [Katharine Susannah] Prichard [Throssell's mother] had been a Soviet agent and that Throssell's role could not be clearly differentiated from hers. The Age more accurately summarises Ball and Horner's conclusion that 'it was unclear whether $\mathrm{Mr}$ Throssell was a Soviet agent or simply an unwitting source of information to his mother, who was a conduit to the Soviets'.

3 Interview Sydney, 19 May 2003. McKnight observed that the Petrovs had claimed that Throssell was working for the Soviets and that most of what the Petrovs said has been borne out.

4 See Richardson, My Father. The author's father 'disappears into the secret world' (p.76) from which his son tries to retrieve him. The son generalises towards the end: '[A]s time passed, he replaced his doubts with convictions and became so absorbed in his war he forgot that happiness was part of wisdom' (p.305). 